\title{
Chromium Removal by Using Chosen Pseudomonads
}

\author{
T. Raghuraman ${ }^{1}$, C. Jerome Ge offrey ${ }^{1}$, S. Suri yanarayanan ${ }^{1}$, A. J. Thatheyus ${ }^{2, *}$ \\ ${ }^{1}$ Department of Immunology and Microbiology, The American College, Madurai, India \\ ${ }^{2} \mathrm{PG}$ and Research Department of Zoology, The American College, Madurai, India \\ *Corresponding author: jthatheyus@y ahoo.co.in
}

Received December 26, 2012; Revised January 18, 2013; Accepted March 03, 2013

\begin{abstract}
Tannery effluent is a major source of aquatic pollution in India. Hexavalent chromium compounds are being used in a wide variety of commercial processes and unregulated disposal of the chromium containing effluent has led to the contamination of soil, sediment, surface and ground waters. In trace amounts, chromiu m is considered an essential nutrient for numerous organisms, but at higher level, it is toxic and mutagenic. Therefore in the present study three strains of Pseudomonas such as Pseudomonas aeruginosa, P. fluorescens strain 1 and 2 were isolated from the collected tannery effluent samples. All the three strains showed more than 60 percentage of reduction for all chromiu m concentrations $(500,1000,1500$ and 2000ppm) tested.
\end{abstract}

Keywords: chromium, tannery, effluent, pseudomonas

\section{Introduction}

Nearly $80 \%$ of the tanneries in India are engaged in the chrome tanning processes. Heavy metals, the major constituents of industrial effluents are not usually eliminated from the aquatic systems by natural processes in contrast to most organic substances. Heavy metals, such as mercury, lead, chro miu m, nickel, copper, cadmium and zinc, are of considerable concern because they are nonbiodegradable, highly toxic and probably carcinogen. They tend to accumulate in bottom sediments from which they may be released by various processes of remobilization and in changing form can move up the food chain and cause various chronic and acute ailments [1].

Wastewater of industries like coil coating, ferroalloys, inorganic chemicals, iron and steel, leather tanning and finishing (including electroplating), petroleum refining, porcelain enameling, textile manufacturing and timber products contain chromium [2]. The toxicology of chromium compounds has been reviewed by USNAS, IARC and Taylor $[3,4,5]$. Chromium $(\mathrm{Cr})$ reacts with nucleic acids and other cell components to produce mutagenic and carcinogenic effects on biological systems [6].

Conventional methods of $\mathrm{Cr}$ removal include chemical reduction followed by ion exchange, precipitation and adsorption on activated coal, alum, kaolinite and ash. But they require large quantities of chemical reagents and high amount of energy [7]. Several treatment processes have been suggested for the removal of heavy met als from aqueous waste streams: adsorption, biosorption, ion exchange, chemical precipitation and electrochemical methods: electrowinning, electrodialysis, electrodeionization, me mbrane-less electrostatic shielding, electrodialys is and electrocoagulation which are highly expensive. But microbial methods are cost effective and efficient[8]. In the present work, an attempt has been made to employ chosen bacteria Pseudomonas aeruginosa and Pseudomonas fluorescens in the biore mediation of tannery effluents.

\section{Materials and Methods}

The tannery effluent samples were collected from the leather industries at Tiruchirapalli and Dindigul in sterile containers. They were brought to the laboratory immediately and analysed for the concentration of chromium using Atomic Absorption Spectrophotometer (AAS). The effluent samples were serially diluted with sterile distilled water and plated on to nutrient agar (Himedia, Bo mbay) medium. The plates were incubated at $37^{\circ} \mathrm{C}$ for 24 hours. Among the bacterial colonies grown, three dominant colonies were selected and cultivated in nutrient broth for eight hours. This three isolated organisms were subjected to biochemical tests for tentative identification following Bergy's manual of Systematic Bacteriology [9].

After testing the resistance of the chosen bacterial strains to different concentrations of chromium prepared by dissolving required amount of potassium chromate $\left(\mathrm{K}_{2} \mathrm{Cr}_{2} \mathrm{O}_{7}\right), 500,1000,1500$ and 2000 ppm concentrations were selected for the experiment. Minimal broth (Dipotassium hydrogen phosphate 7g; Potassium dihydrogen phosphate $2 \mathrm{~g}$; Ammonium sulphate 1g; Glucose 1g; Sodium citrate 0.5g; Magnesium sulphate $0.1 \mathrm{~g}$ made upto 1litre.) was prepared and autoclaved at $115^{\circ} \mathrm{C}$ for 15 minutes and was cooled in a water bath at $45-50^{\circ} \mathrm{C}$. In $250 \mathrm{ml}$ Erlenmeyer flasks, $100 \mathrm{ml}$ minimal broth was taken along with the above mentioned concentration of chromium. Under aseptic conditions, the three chosen organisms were inoculated individually into these flasks with $10^{9}$ cells $(0.1 \mathrm{ml})$. The flasks were incubated at room temperature. Uninoculated control flasks were also maintained in the same manner. After 
forty days, samples were taken from each flask and centrifuged at $10,000 \mathrm{rpm}$ for ten minutes. The supernatants were analysed with AAS for chromium concentration adopting standard methods [10]. Percentage reduction in chromium concentration was calculated for each chromiu m concentration based on the initial and final readings.

\section{Results and Discussion}

Table 1 shows the concentration of chromium present in the samples of tannery effluent collected from Tiruchirapally and Dindigul. Among them, the samples collected from Dindigul exhibited higher levels than that of Tiruchirappalli. Table 2 divulges the culture characteristics of the isolated strains. Based on Gram's staining, motility and other biochemical tests, the three strains were tentatively identified as Pseudomonas aeruginosa, $P$. fluorescens strain 1 and 2.

Table 1.Concentration of Chromium in the TanneryEffluent Samples Collected from Trichirapalli and Dindigul

\begin{tabular}{|c|c|c|}
\hline Sl.No & Samples & Cr concentration(ppm) \\
\hline 1 & T1 & 1120 \\
\hline 2 & T2 & 1200 \\
\hline 3 & D1 & 1520 \\
\hline 4 & D2 & 1532 \\
\hline
\end{tabular}

$\mathrm{T}=$ Trichirapalli; $\mathrm{D}=$ Dindigul

Table 2. Cul ture Characteristics of Pseudomonas aeruginosa and Pseudomonas fluorescens isolated from Tannery Effluent

\begin{tabular}{|c|c|c|c|}
\hline \multirow[b]{2}{*}{$\begin{array}{l}\text { Name of the } \\
\text { Test }\end{array}$} & \multicolumn{3}{|c|}{ Test Organisms } \\
\hline & $\begin{array}{c}\text { Pseudomonas } \\
\text { aeruginosa }\end{array}$ & $\begin{array}{c}\text { Pseudomonas } \\
\text { fluorescens- } \\
\text { strain } 1 \\
\end{array}$ & $\begin{array}{l}\text { Pseudomonas } \\
\text { fluorescens- } \\
\text { strain } 2 \\
\end{array}$ \\
\hline Morphology & $\mathrm{G}+$ & $\mathrm{G}+$ & $\mathrm{G}+$ \\
\hline Motility & + & + & + \\
\hline $\begin{array}{c}\text { Indole } \\
\text { Production }\end{array}$ & + & - & - \\
\hline Methyl Red & - & + & + \\
\hline $\begin{array}{c}\text { Voges } \\
\text { Proskaeur }\end{array}$ & + & + & + \\
\hline $\begin{array}{c}\text { Citrate } \\
\text { Utilization }\end{array}$ & + & - & - \\
\hline $\begin{array}{c}\mathrm{H}_{2} \mathrm{~S} \\
\text { Production }\end{array}$ & - & + & + \\
\hline $\begin{array}{c}\text { Glucose } \\
\text { Fermentation }\end{array}$ & + & - & - \\
\hline $\begin{array}{c}\text { Lactose } \\
\text { Fermentation }\end{array}$ & - & - & - \\
\hline $\begin{array}{c}\text { Sucrose } \\
\text { Fermentation }\end{array}$ & - & - & - \\
\hline Coagulase & - & - & - \\
\hline Catalase & + & + & + \\
\hline Oxidase & + & + & + \\
\hline Urease & + & - & - \\
\hline $\begin{array}{c}\text { Esculin } \\
\text { Hydrolysis }\end{array}$ & - & - & - \\
\hline $\begin{array}{c}\text { Nitrate } \\
\text { Reduction }\end{array}$ & + & - & - \\
\hline
\end{tabular}

All the three microorganisms tested for chromium removal were capable of removing chromium (Table 3 ). Among them, maximum removal was exhibited by $P$. aeruginosa for $500 \mathrm{ppm}$ of initial concentration. For 2000 ppm of initial chromium concentration, maximum removal of chromium was noticed for $P$. aeruginosa followed by $P$. fluorescens strain 1 and 2 . All the three strains showed more than 60 percentage of reduction for all chro miu m concentrations tested.
Table 3. Reduction in Chromium Concentration After40 days of Treatment

\begin{tabular}{|c|c|c|c|}
\hline $\begin{array}{c}\text { Bacterial } \\
\text { strains }\end{array}$ & $\begin{array}{c}\text { Initial } \\
\text { concentration } \\
(\mathrm{ppm})\end{array}$ & $\begin{array}{c}\text { Final } \\
\text { concentration } \\
(\mathrm{ppm})\end{array}$ & $\begin{array}{c}\text { Percentage } \\
\text { of reduction }\end{array}$ \\
\hline Pseudomonas & 1000 & 44.06 & 91.20 \\
aeruginosa & 1500 & 205.20 & 80.70 \\
& 2000 & 789.60 & 77.40 \\
\hline Pseudomonas & 500 & 62.40 & 72.30 \\
fluorescens & 1000 & 243.80 & 87.20 \\
strain1 & 1500 & 463.80 & 75.62 \\
\hline Pseudomonas & 5000 & 733.60 & 67.36 \\
fluorescens & 1000 & 64.00 & 87.20 \\
strain2 & 1500 & 241.00 & 75.90 \\
\hline
\end{tabular}

Heavy metals released into the environment as a consequence of rapid industrialization pose a serious environmental threat as they derail the normal physiology by forming metabolically unspecific complexes. Their continuous presence in nature has in turn resulted in the development of metal resistant strains. These strains counteract the heavy metal toxicity by complexation or precipitation or accumulation of heavy metals inside the cell. As chemical methods are costly, bioremediation is a cheaper way to remove chromium from effluents. It is a process of trapping of metal ions outside or inside the cell. Different types of microbes like bacteria, algae, fungi and yeast are involved in bioremediation. They differ in their intrinsic capabilities and mechanisms of metal removed and interact with heavy metals by precipitation, intracellular accumulation, metal transformation and extracellular metal co mple xation [11].

In the present work both the isolates of Pseudomonas aeruginosa and Pseudomonas fluorescens were able to cause the removal of chromium. Among them Pseudomonas aeruginosa is better and in all the three strains increase in $\mathrm{Cr}$ concentration hindered the process of $\mathrm{Cr}$ removal. But even at 2000ppm $\mathrm{Cr}$ concentration all of themexhibited more than $60 \%$ reduction in the level of chromium in solution. Even at 2000ppm they were able to remove chromium, as they were isolated from tannery effluent contaminated sites having $\mathrm{Cr}$ concentration as high as $2000 \mathrm{ppm}$ and they would have adapted to such high concentrations.

$\mathrm{Cr}^{6+}$ concentration affects the growth of bacteria. Bacillus spp. was able to grow even above 1000ppm of $\mathrm{Cr}^{+}$but its growth decreased to $50 \%$ at $1500 \mathrm{ppm}$ [12]. At 10 and $12 \mathrm{ppm} \mathrm{Cr}^{6+}$ exerts toxic and mutagenic effects on microbes and inhibits growth of soil bacteria in liquid media. Such toxic effects are due to the alteration of genetic material and altered metabolic and physiological reaction [13].

Chromate is a strong oxidizing agent and gets reduced intracellularly to $\mathrm{Cr}^{5+}$ which can react with nucleic acids and other cell components to cause mutagenic and carcinogenic effects [6]. Though some microbes like Pseudomonas fluorescens [14], Enterobacter cloacae and Bacillus spp.,[15] posses the capacity to reduce $\mathrm{Cr}^{6+}$ to $\mathrm{Cr}^{3+}$, the potential for bioremediation of chromiu m wastes is limited because of some mic robes losing their viability in high concentration of chromate [16].

Microbes with the ability to tolerate and reduce hexavalent chromium can be used for detoxification of environments contaminated with $\mathrm{Cr}^{6+}$. Reduction of hexavalent chromium into trivalent chromium is a 
potentially useful process for remediation of chromiumcontaminated environments [17]. Bioreduction of hexavalent chromium can occur directly as a result of microbial metabolism through enzymes or indirectly, by a bacterial metabolite like $\mathrm{H}_{2} \mathrm{~S}$ [13]. In bacteria, chromium reduction is dependent on $\mathrm{pH}$, temperature and $\mathrm{Cr}$ concentration. The optimu $\mathrm{mpH}$ is found to be 7 to 9 . As hexavalent chromium reduction is enzyme-mediated, changes in $\mathrm{pH}$ will affect the degree of ionization of the enzyme, changing the protein's conformation and affecting the enzy me activity [18].

In many instances chromate resistance is due to the presence of efflux mechanisms, which allow resistant strains to extrude chromate ions. Hence some of the microbes like Pseudomonas aeruginosa, Pseudomonas fluorescens, Alcaligenes eutrophus and Enterobacter cloacae exhibited low uptake [16]. It was suggested that bacterial chromate reduction and resistance are independent processes. Two en zy matic mechanisms were identified in microbe-mediated $\mathrm{Cr}$ (VI) reduction [19].

Reduced chromium is complexed with soluble organic compounds like electronegative exopolymers liberated from capsules [20]. In bacteria like Pseudomonas fluorescens LB300, Pseudomonas aeruginosa, Pseudomonas putida and Alcaligenes eutrophus, $\mathrm{Cr}$ resistance was offered by a plas mid via decreased uptake of the metal [21,22]. In Pseudomonas aeruginosa and Alcaligenes eutrophus, $\mathrm{Chr} \mathrm{A}$, a membrane protein confers tolerance by extrusion of chro mate ions [23] while in $P$. ambigua G1, a capsule inhibits the entry of chromate ions [24].

In the chromate reducing Pseudomonad, cell envelope and capsule exopolymer chromium complexation inhibited the metal from entering the cytoplasm. When $\mathrm{Cr}$ (VI) is reduced to $\mathrm{Cr}$ (III), it is free to bind to the electronegative charged surface functional groups on the cell surface, which serve as nucleation sites for further precipitation so that chromate is removed from solution [25]. The isolates tested in this work show promise for chromium removal and they can be employed in the bioremediation of chro miu m-contaminated sites.

\section{Acknowledgements}

The authors thank the UGC, New Delhi for financial assistance in the form of Major Research Project (F.No.40-368/2011 (SR)) and the authorities of the American College for the facilities.

\section{References}

[1] Forstner, U and G.T.W.Wittmann, Metal Pollution in the Aquatic Environment. Springer verlag. New York. 485, 1983.

[2] TOWILL, L.E., C.R.Shriner and J.S.Drury, Reviews of the Environmental effects of Pollutants. III. Chromium. Report, May 1978.

[3] USNAS, Chromium. U.S. National Academy of Sciences, Washington, 155, 1974.

[4] IARC, Chromium and chromium compounds. In: Some metals and metallic compounds. International Agency for Research on Cancer Monographs, 23, 205-323, 1980.
[5] Taylor, A, Summary of the data on the toxicity of various materials to aquatic life. II. Chromium. Report of the Brixham Laborat ory, BL/A/2127, 1981.

[6] McLean, J and Beveridge T.J., "Chromate reduction by a pseudomonad isolated from a site contaminated with chromated copper arsenate", Appl. Environ. Microbiol, 67(3), 1076-1084, March, 2001.

[7] Komori, K., Rivas, A., Toda, K and Ohtake, H., "A method for removal of toxic chromium using dialysis-sac cultures of a chromate-reducing strain of Enterobacter cloacae", Appl. Microbiol. Biotechnol, 33(1), 117-119, April, 1990.

[8] Ganguli, A and Tripathi, A.K., "Bioremediation of toxic chromium from electroplating effluent by chromate-reducing Pseudomonas aeruginosa A2Chr in two bioreactors", Appl. Microbiol. Biotechnol, 58(3), 416-420, November, 2002.

[9] Krieg, N.R and J.G. Holt, Bergey's manual of systemic bacteriology. Vol.1 William and Wilkins, Baltimore, USA.1984

[10] APHA, Standard methods for the examination of water and waste water. $19^{\text {th }}$ edn. APHA, AWWA, WPCF, USA. 1995.

[11] Paknikar, K.M., Pethkar A.V and Puranik, P.R., "Bioremediation of metalliferous wastes and products using inactivated microbial biomass", Indian J. Biotechnol., 42(1), 426-433, July, 2000.

[12] Camargo, F.A.O., Bento F.M. and by chromium- Frankenberger, "Chromate reduction resistant bacteria isolated from soils contaminated with Dichromate", J. Environ. Qual., 32(4), 12281233, 2003.

[13] Losi, M.E., Amrhein C and Frankenberger, W.T., "Environmental biochemistry of chromium", Rev. Environ. Contam. Toxicol, 136(1): 91-121, November, 1994.

[14] Bopp, L.H and Ehrlich, H.L., "Chromate resistance and reduction in Pseudomonas fluorescens srain LB300", Arch. Microbiol., 150(50): 426-431, September, 1988.

[15] Wang, P.C., Mori T and Komori K.,Sasatsu, M., Toda, K and Ohtake H., "Isolation and characterization of an Enterobacter cloacae strain that reduces hexavalent chromium under anaerobic conditions",Appl. Microbiol. Biotechnol., 55 (7): 1665-1669, July, 1989.

[16] Pattanapipitpaisal, P., Brown, N.L and Macaskie, L.E., "Chromate reduction and $16 \mathrm{~S}$ rRNA Identification of bacteria isolated from a Cr(VI)- contaminated site", Appl. Microbiol. Biotechnol., 57 (1-2), 257-261,October, 2001

[17] Michel, C., Brugma M., Aubert, C., Bernadac A and Bruschi, M. "Enzymatic reduction of chromate: comparative studies using sulfate-reducing bacteria", Appl. Microbiol. Biotechnol, 55 (2):95100. January, 2001.

[18] Farrell, S.O. and R.T.Ranallo, Experiments in Biochemistry. A hands-on approach, Saunders College Pub, 2000, Orlando.

[19] Chen, J.M. and Hao, O.J., "Environmental factors and modeling in microbial chromium (VI) reduct ion", Water Environ. Chem., 68(7): 1156-1164, November, 1996.

[20] Geesey, G.G. and L. Jang, Interactions between metal ions and capsular polymers. In: Metal ions and bacteria, John Wiley and Sons, New York, USA, 325-358, 1989.

[21] Mondaca, M.A., Gonzalez C.L and Zaror C.A., "Isolation, characterization and expression of a plasmid encoding chromate resistance in Pseudomonas putida KT2441", Lett. Appl. Microbiol, 26(5), 367-371, May 1998.

[22] Nies, D.H and Silver, S., "Plasmid-determined inducible efflux is responsible for resistance to cadmium, zinc and cobalt in Alcaligenes eutrophus", J. Bacteriol, 171(2), 896-900, February, 1989.

[23] Alvarez, A.H., Moreno-Sanchez, R and Cervantes, C., "Chromate efflux by means of the ChrA chromate resistance protein from Pseudomonas aenuginosa ", Appl. Microbiol. Biotechnol, 181(23), 7398-7400, December, 1999.

[24] Horitsu, H.,Futo, S and Miyazawa, Y., 'Enzymatic reduction of hexavalent chromium by hexavalent chromium tolerant Pseudomonas ambigua G-1”,Agric. Boil. Chem, 51(9), 2417-2420, March, 1987.

[25] Beveridige, T.J and Murray, R.G.E., "Uptake and retention of metals by cell walls of Bacillus subtilis", J. Bacteriol, 127(3), 1502-1518, September, 1976. 